\title{
EVALUASI BESAR BUTIR TERHADAP SIFAT MEKANIS CUZn70/30 SETELAH MENGALAMI DEFORMASI MELALUI CANAI DINGIN
}

\author{
Riyan Sanjaya ${ }^{1)}$ dan Eddy S. Siradj ${ }^{2)}$ \\ ${ }^{1)}$ Program Studi Teknik Mesin, Fakultas Teknik Universitas Tarumanagara, Jakarta \\ ${ }^{2)}$ Departemen Material dan Metalurgi Fakultas Teknik Universitas Indonesia, Jakarta \\ e-mail: nyongs88@Hotmail.com
}

\begin{abstract}
The research was conducted because of the many industries that use CuZn 70/30 as a raw material in industrialization. CuZn 70/30 was studied to obtain the strong mechanical properties of brass. Research CuZn 70/30 was evaluated using a process of heating of about $615^{\circ} \pm 5^{\circ} \mathrm{C}$ and then held for 90 minutes. The next process is the process of cold rolling by using a variety of reduction and then tested by using a Vickers hardness testing, tensile testing, observation of the microstructure. The result of this research is a fine microstructure (below $10 \mu \mathrm{m}$ ), hardness (HV 211.67). Tensile test also conducted to get how much resistance CuZn 70/30 to resist the pull. The cold rolling process causing the decrease the mechanical properties and also increase the plastic properties of the brass.
\end{abstract}

Keywords: brass, heat treatment, mechanical properties and microstructure

\section{PENDAHULUAN}

Industri kuningan pada saat ini merupakan salah satu industri yang sangat menunjang dalam sektor ekonomi indonesia. Kuningan merupakan paduan antara tembaga $(\mathrm{Cu})$ dengan seng $(\mathrm{Zn})$ yang banyak digunakan sebagai kebutuhan dibidang industri dalam membuat komponen-komponen meliputi pekerjaan arsitekturat, pipa kondensor, keran, inti radiator, pegas mur-baut dan lain-lain.

Perkembangan jaman yang begitu pesat hari ke hari, menuntut semakin meningkatnya sifat material, baik mekanik maupun fisiknya. Pada berbagai aplikasi, material-material kini harus dapat beradaptasi dengan permintaan konsumen yang semakin tinggi. Material logam, contohnya, dituntut untuk memiliki kekuatan yang besar namun juga harus memiliki keuletan dan ketangguhan yang tinggi. Untuk memenuhi tuntutan jaman itu, bermacam penelitian dilakukan untuk mendapatkan sifat mekanik material logam yang lebih baik. Bererapa proses seperti Heat Treatment atau perlakuan panas semakin dikembangkan untuk mendapat kekuatan dan ketangguhan secara bersamaan. Selain itu salah satu usaha peningkatan sifat mekanik juga dilakukan dengan cara mendapatkan superplastisitas material.

Superplastisitas adalah proses difusi terkontrol yang terjadi pada temperatur tinggi dalam material dimana ukuran butir mencapai 1-10 $\mu \mathrm{m}$. Material yang memiliki butir halus akan memiliki kekuatan yang lebih besar dibandingkan material dengan butir kasar. Deformasi pada material, dalam skala mikro, merupakan perubahan bentuk akibat adanya pergerakan atom-atom yang berakhir pada permukaan. Material dengan butir yang lebih halus, pergerakan atomnya akan lebih cepat berhenti akibat sulitnya pergerakan atom oleh karena banyaknya batas butir. Semakin banyak batas butir, energi yang diperlukan untuk melewatinya akan semakin besar sehingga dibutuhkan lebih banyak tenaga untuk mendeformasi material tersebut, atau dengan kata lain material tersebut semakin keras. Dengan adanya penghalusan butir juga akan menurunkan rasio berat terhadap kekuatan, yang akan berguna dalam aplikasi kuningan tersebut.

Pada penelitian ini berjudul Studi Sifat Mekanis Kuningan dengan Kadar CuZn 70/30. Dengan proses cold rolling dengan derajat reduksi yang besar merupakan bahan baku pembuatan selongsong peluru yang akan diproduksi di dalam negeri. Dalam penelitian saya ini dilakukan produksi didalam negeri. Dalam penilitan ini dilakukan penganilan pada pelat kuningan, proses rolling, uji struktur mikro, uji tarik, dan uji kekerasan. Bagaimana karakteristik strukstur mikro dan pengujian sifat mekanis pada saat proses cold rolling serta melihat pengaruh ukuran butir terhadap sifat mekanik?

Dalam topik yang akan dibahas ini, dilakukan pembatasan masalah antara lain: Proses penganilan dengan suhu $615^{\circ} \mathrm{C} \pm 5^{\circ} \mathrm{C}$ dengan waktu 90 menit, Proses cold rolling, uji kekerasan dengan metode vickers, pengamatan metalografi, dan uji tarik. Setelah proses cold rolling akan 
dilihat pengaruh mikro struktur dan sifat mekanis. Dalam penelitian ini akan terlihat berapa besar pengaruh reduksi dan regangan pada cold rolling. Melihat struktur mikro dari setiap tahapan proses yang berkaitan dengan ukuran butir. Untuk mengetahui kekerasan sebelum dan sesudah cold rolling.

\section{METODE PENELITIAN}

Metodologi penelitian dilakukan untuk menentukan tujuan dari penelitian, menentukan prosedur penelitian, melakukan pengujian dan analisa hasil pengujian. Tahapan penelitian tersebut disusun agar penelitian berjalan secara sistematis. Langkah-langkah untuk penelitian ini adalah seperti diagram alir dibawah ini. Setelah pengujian dilakukan maka akan didapatkan data-data yang akan dianalisa lebih lanjut.

Diagram alir proses penelitian dimulai dengan pesiapan sampel kuningan yang dipotong dengan ukuran (h x w x l: 7 x 9 x $80 \mathrm{~mm}$ ). Kemudian dilakukan proses anil dengan temperatur $615^{0} \pm 5^{\circ} \mathrm{C}$. Setelah itu dilakukan pengerolan dan dilanjutkan dengan metalografi, pengujian kekerasan dengan metode Vickers, dan uji tarik. Tahap berikut dilakukan pembahasan dan analisa dari pengujian yang dilakukan. Tahap akhir ialah pembuatan kesimpulan.

\section{HASIL DAN PEMBAHASAN}

Dari pengerolan beberapa sampel pelat kuningan CuZn 70/30 dengan ketebalan awal yang sama diperoleh hasil seperti yang dapat dilihat pada Tabel $1-4$.

Tabel 1. Data hasil pengerolan pelat dengan 6 kali pas

\begin{tabular}{|c|c|c|c|c|c|}
\hline \multirow{8}{*}{ Sampel 14} & Jumlah pas & $\mathrm{h}_{0}(\mathrm{~mm})$ & \multicolumn{3}{|c|}{ Besar reduksi } \\
\hline & \multicolumn{3}{|c|}{7} & & \\
\hline & 1 & 7 & 5,49 & 21,57 & 0,24 \\
\hline & 2 & 7 & 4,43 & 36,71 & 0,45 \\
\hline & 3 & 7 & 3,56 & 49,14 & 0,67 \\
\hline & 4 & 7 & 2,54 & 63,71 & 1,01 \\
\hline & 5 & 7 & 1,83 & 73,85 & 1,34 \\
\hline & 6 & 7 & 1,53 & 78,14 & 1,52 \\
\hline
\end{tabular}

Tabel 2. Data hasil pengerolan pelat dengan 5 kali pas

\begin{tabular}{|c|c|c|c|c|c|}
\hline \multirow{7}{*}{ Sampel 4} & Jumlah pas & $\mathrm{h}_{0}(\mathrm{~mm})$ & \multicolumn{3}{|c|}{ Besar reduksi } \\
\hline & \multicolumn{3}{|c|}{7} & & \\
\hline & 1 & 7 & 5,51 & 21,28 & 0,23 \\
\hline & 2 & 7 & 4,38 & 37,42 & 0,46 \\
\hline & 3 & 7 & 3,12 & 55,42 & 0,80 \\
\hline & 4 & 7 & 2,16 & 69,14 & 1,17 \\
\hline & 5 & 7 & 1,49 & 78,71 & 1,54 \\
\hline
\end{tabular}

Setelah proses pengerolan dilakukan preparasi sampel untuk dilakukan metalografi untuk mendapatkan foto struktur mikro dan uji kekerasan vickers. Pengambilan sampel dilakukan berdasarkan besar reduksi atau regangan.

Setelah metalografi foto struktur mikro dilakukan uji kekerasan Vickers dengan masingmasing 3 titik untuk setiap kondisi regangan (reduksi). Dari foto struktur mikro dan pengujian 
Vickers dilakukan pengukuran butir rata-rata pada Tabel 5 dapat dilihat hasil uji kekerasan dan butir rata-rata pada berbagai kondisi regangan (reduksi).

Tabel 3. Data hasil pengerolan pelat dengan 4 kali pas

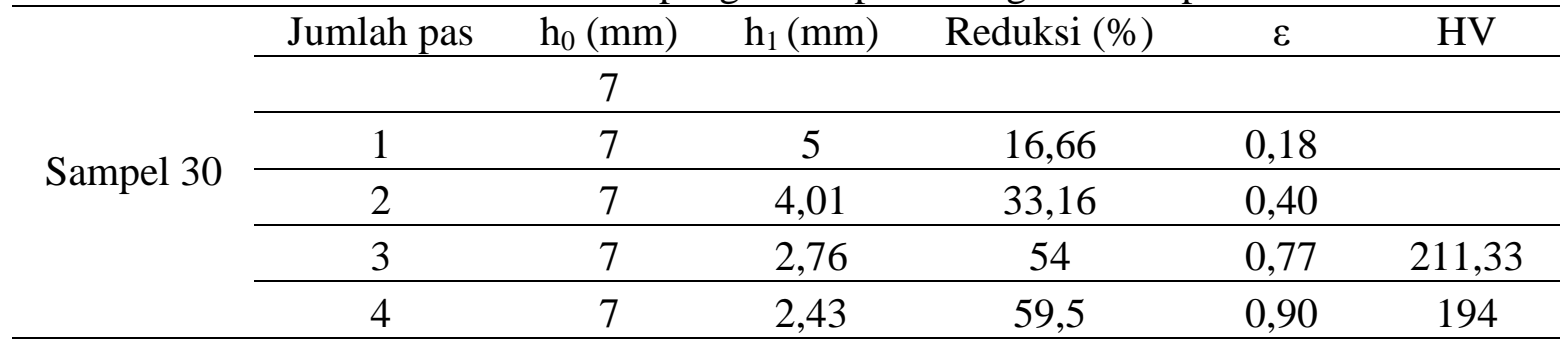

Tabel 4. Data hasil pengerolan pelat dengan 4 kali pas

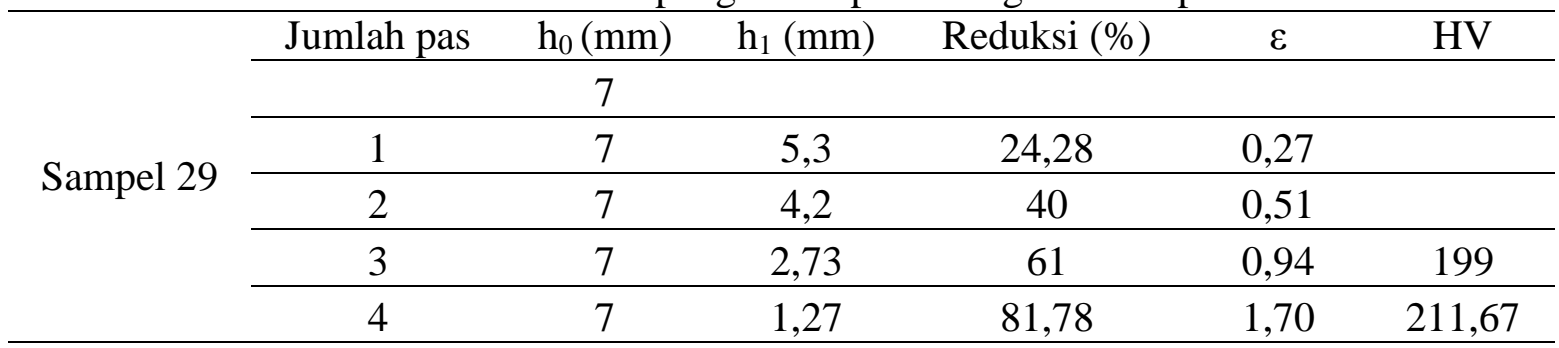

Tabel 5. Hasil dari pengujian kekerasan Vikers dan besar butir struktur mikro

\begin{tabular}{ccccc}
\hline Sampel & Reduksi $(\%)$ & $\varepsilon$ & HV & Diameter butir $(\mu \mathrm{m})$ \\
\hline Awal & 0 & 0 & 77 & 30 \\
\hline \multirow{3}{*}{ Sampel 4 } & 37,43 & 0,47 & 168,67 & 10,3 \\
\cline { 2 - 5 } & 69,14 & 1,18 & 194,33 & 8,66 \\
\cline { 2 - 5 } & 78,71 & 1,55 & 204 & 5,49 \\
\hline \multirow{3}{*}{ Sampel 14 } & 36,71 & 0,46 & 181,33 & 6,23 \\
\cline { 2 - 5 } & 63,71 & 1,01 & 196 & 5,51 \\
\cline { 2 - 5 } & 78,14 & 1,52 & 216,67 & 4,56 \\
\hline \multirow{2}{*}{ Sampel 29 } & 61,00 & 0,94 & 199 & 6,35 \\
\cline { 2 - 5 } & 81,79 & 1,70 & 211,67 & 3,84 \\
\hline \multirow{2}{*}{ Sampel 30 } & 54,00 & 0,78 & 194 & 7,02 \\
\cline { 2 - 5 } & 59,50 & 0,90 & 211,33 & 3,92 \\
\hline
\end{tabular}

Berikut ini adalah gambar dari struktur mikro hasil dari proses metalografi dengan perbesaran $500 \mu \mathrm{m}$.

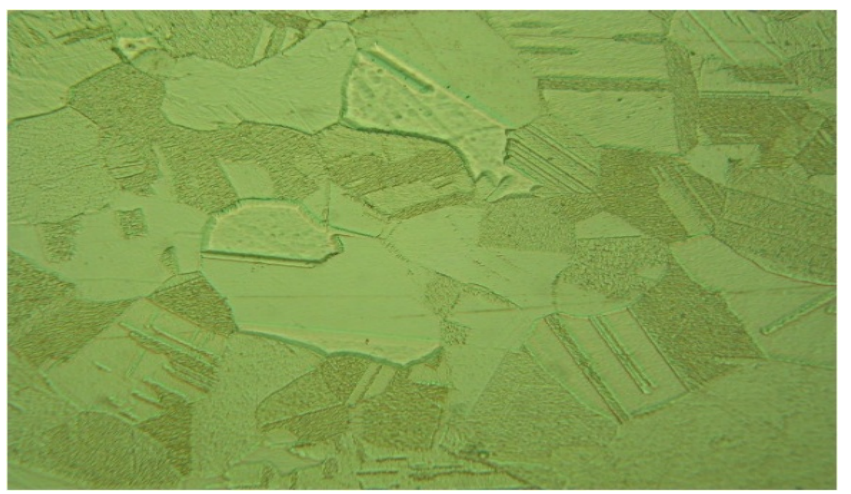

Gambar 1. Foto struktur mikro setelah mengalami proses anil dengan perbesaran 500 kali. 
(a). sampel $4.1(\varepsilon=0,46)$

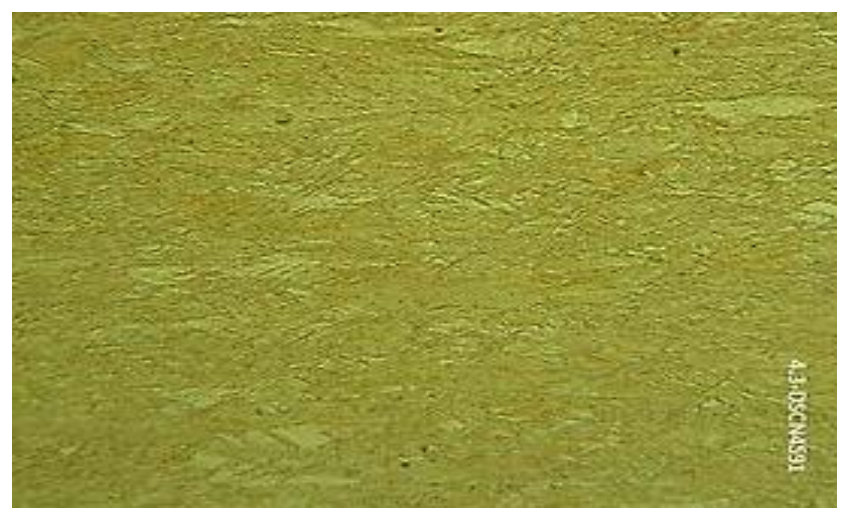

(c). sampel $4.3(\varepsilon=1,54)$

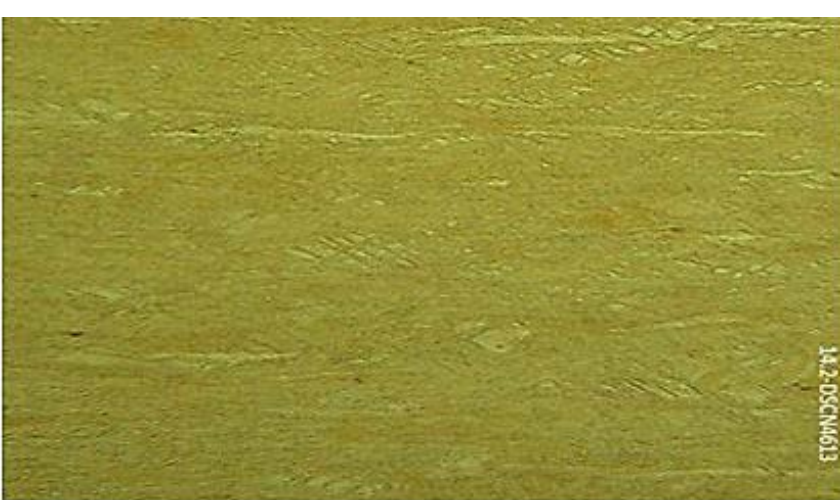

(e). sampel $14.2(\varepsilon=1,01)$ (b). sampel $4.2(\varepsilon=1,17)$

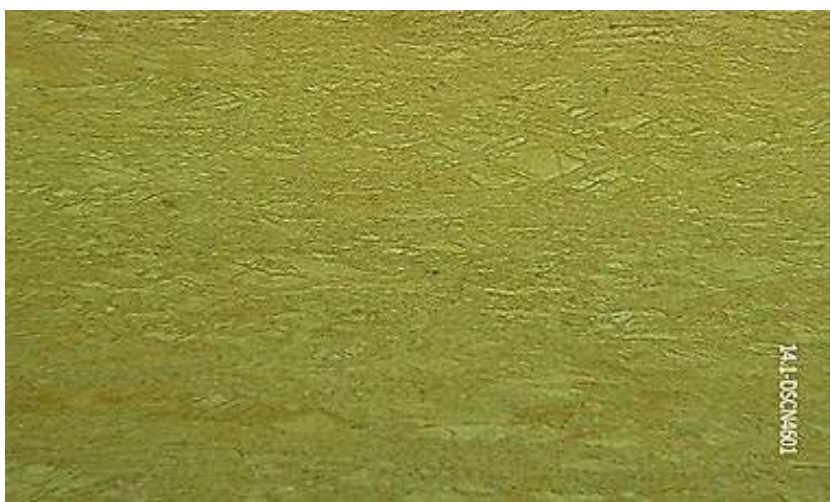

(d). sampel $14.1(\varepsilon=0,45)$

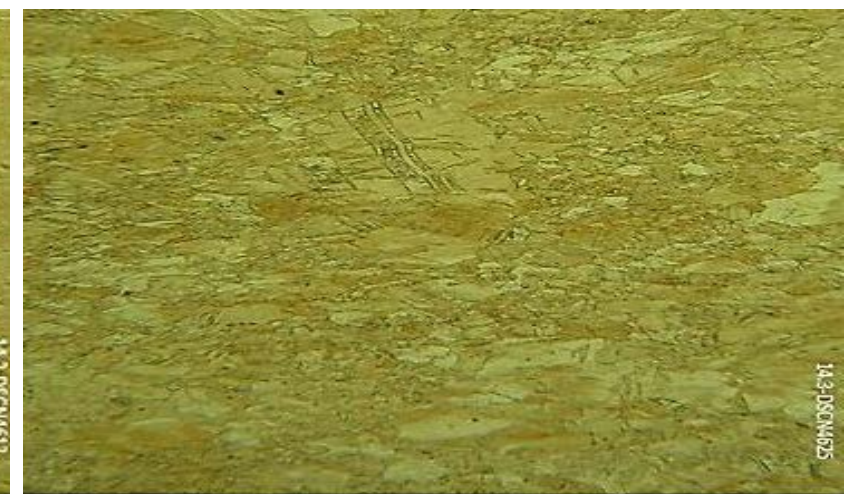

(f). sampel $14.3(\varepsilon=1,52)$

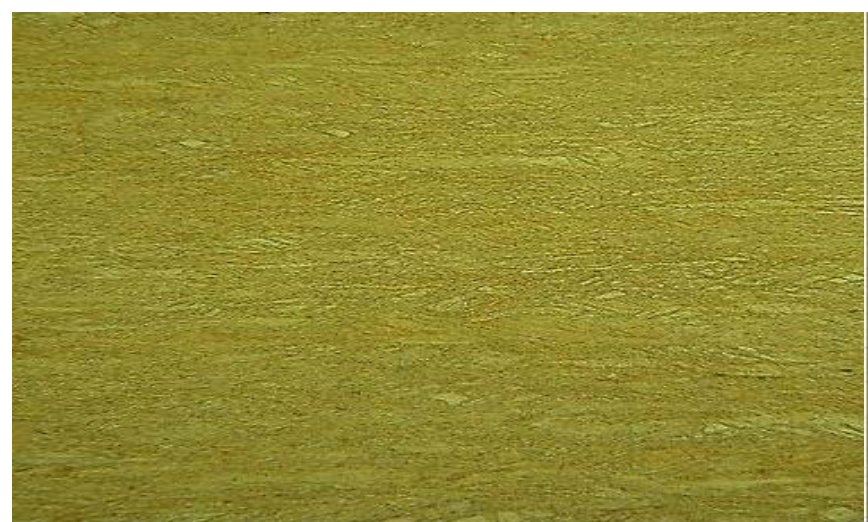

(c). sampel $29.1(\varepsilon=0,9)$

(d). sampel $29.2(\varepsilon=1,70)$

Gambar 2. Foto struktur mikro sampel dengan perbesaran 500 kali 
(c). sampel $30.1(\varepsilon=0,77)$

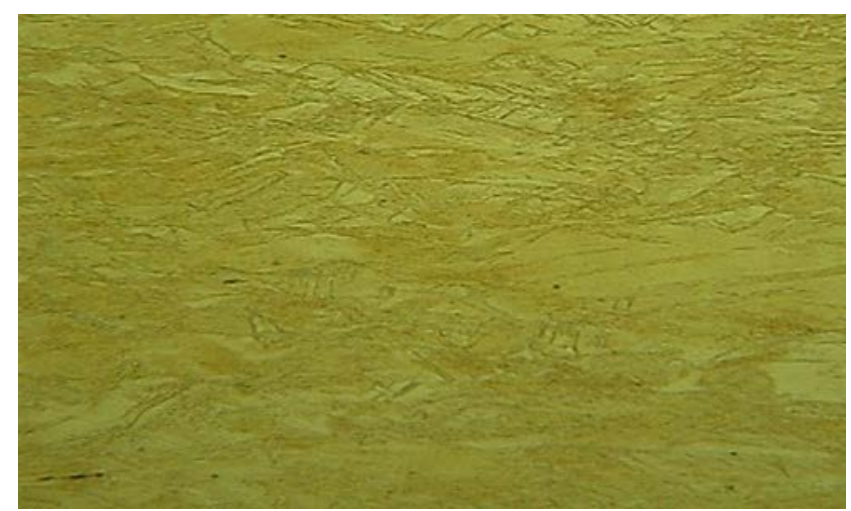

(d). sampel $30.2(\varepsilon=0,90)$

Lanjutan Gambar 2. Foto struktur mikro sampel dengan perbesaran 500 kali

Berikut ini adalah grafik hubungan antara regangan terhadap diameter butir.

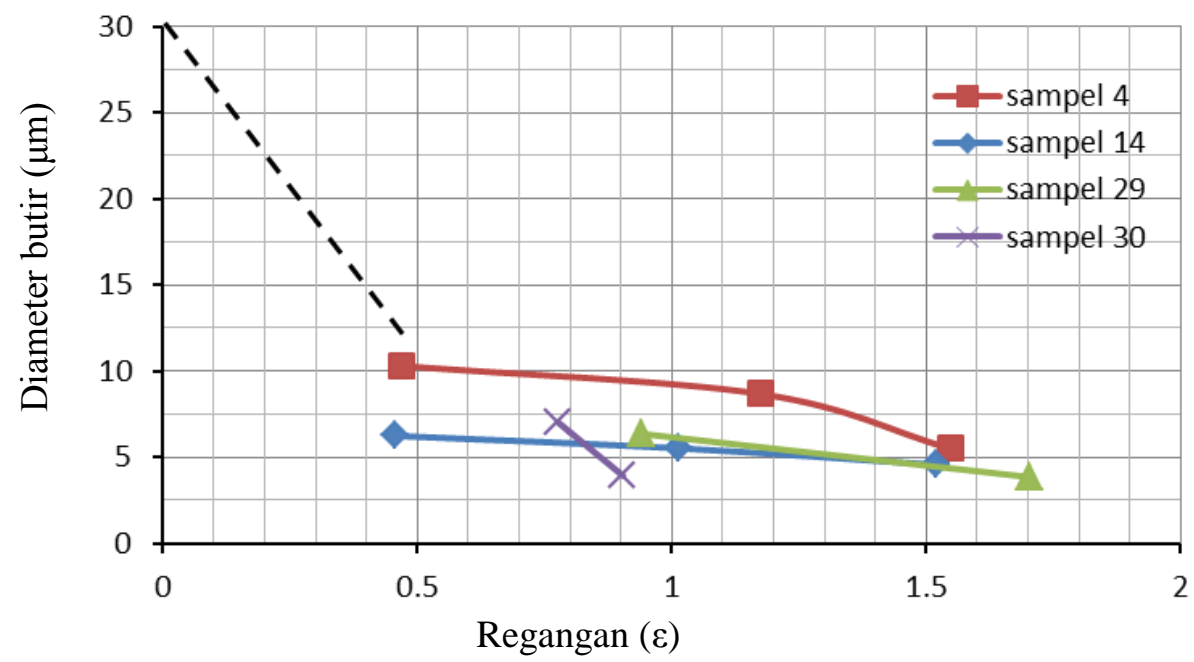

Gambar 3. Grafik hubungan antara regangan deformasi dengan butir besar rata - rata

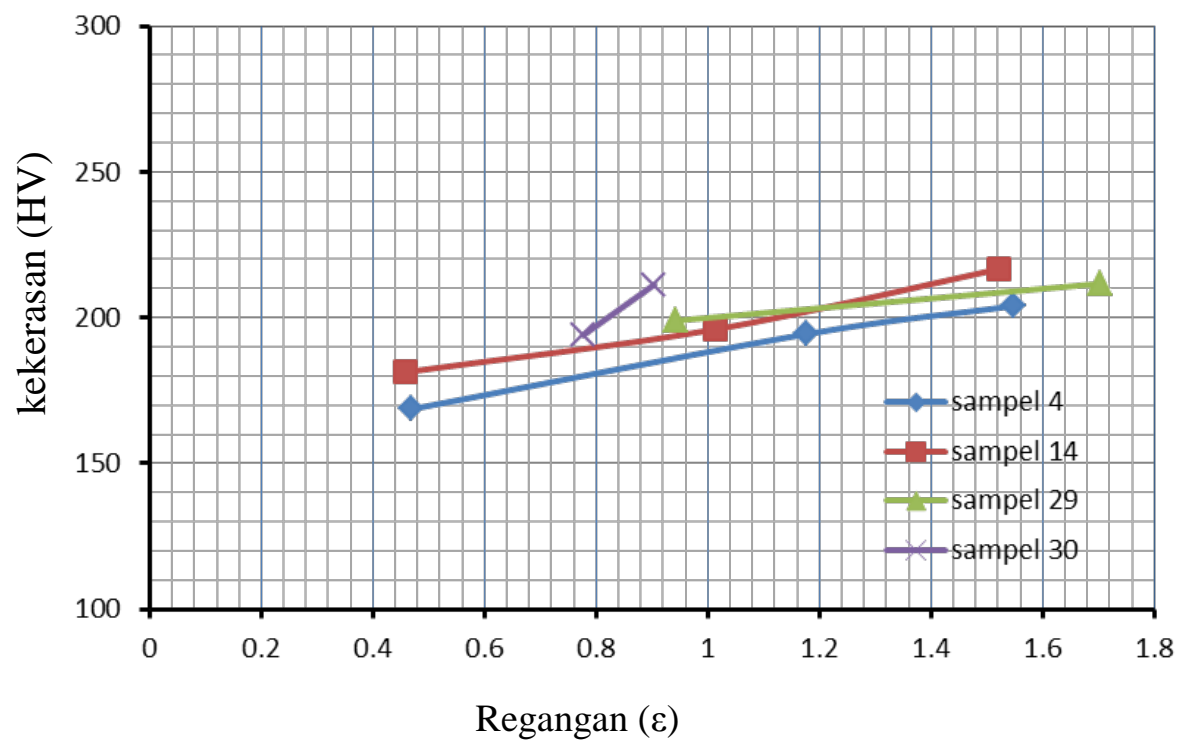

Gambar 4. Hubungan antara regangan dengan kekerasan Vickers 


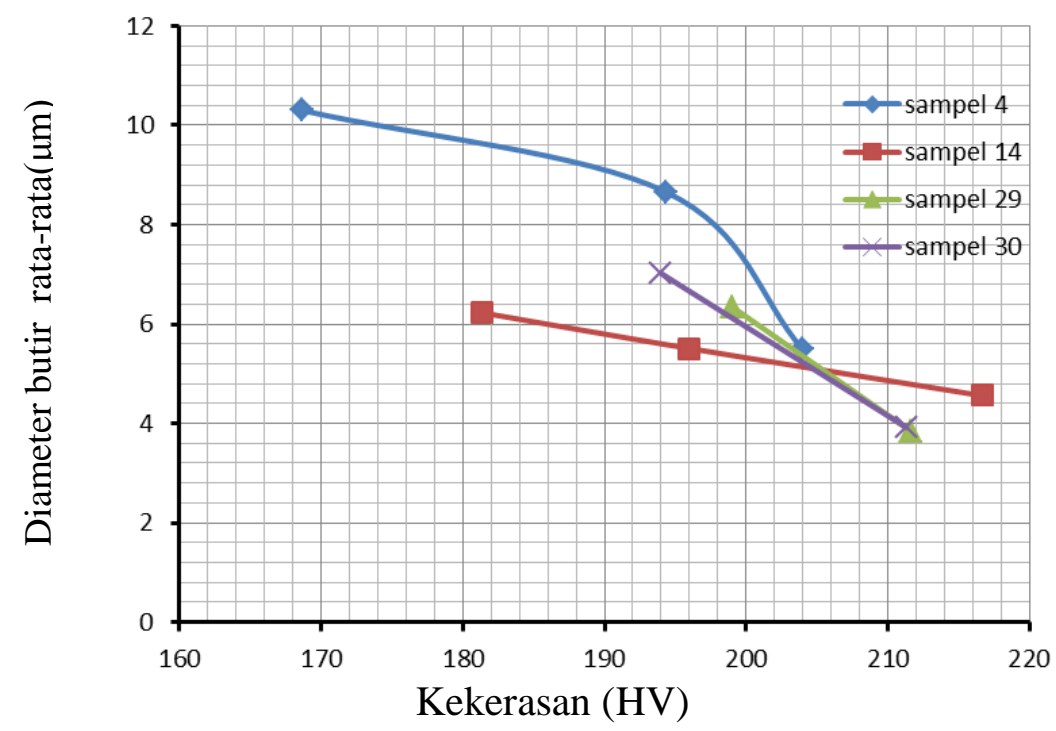

Gambar 5. Grafik hubungan antara kekerasan Vickers dengan diameter butir rata-rata

Setelah proses pengerolan, pengujian kekerasan, dan metalografi dilakukan maka dilanjutkan dengan pengujian tarik dengan standard ASTM-A370.

Tabel 6. Hasil uji tarik

\begin{tabular}{ccccccc}
\hline$\varepsilon$ & $\mathrm{h}_{0}(\mathrm{~mm})$ & $\mathrm{D}(\mathrm{mm})$ & $\mathrm{L}_{0}(\mathrm{~mm})$ & $\mathrm{A}_{0}\left(\mathrm{~mm}^{2}\right)$ & $\begin{array}{c}\text { yield strength } \\
\left(\mathrm{N} / \mathrm{mm}^{2}\right)\end{array}$ & $\begin{array}{c}\text { tensile strength } \\
\left(\mathrm{N} / \mathrm{mm}^{2}\right)\end{array}$ \\
\hline 1,8 & 1,1 & 6,4 & 45 & 49,5 & 76,3 & 93,14 \\
2,1 & 0,9 & 6,4 & 45,4 & 40,86 & 76,82 & 99,63 \\
1,6 & 1,4 & 6,5 & 46 & 64,4 & 69,3 & 86,06 \\
1,54 & 1,5 & 6,4 & 45 & 67,5 & 37,06 & 82,47 \\
0,9 & 2,8 & 6,5 & 44 & 123,2 & 11,14 & 71,66 \\
0 & 7 & 12,5 & 57 & 399 & 32,45 & 78,67 \\
\hline
\end{tabular}

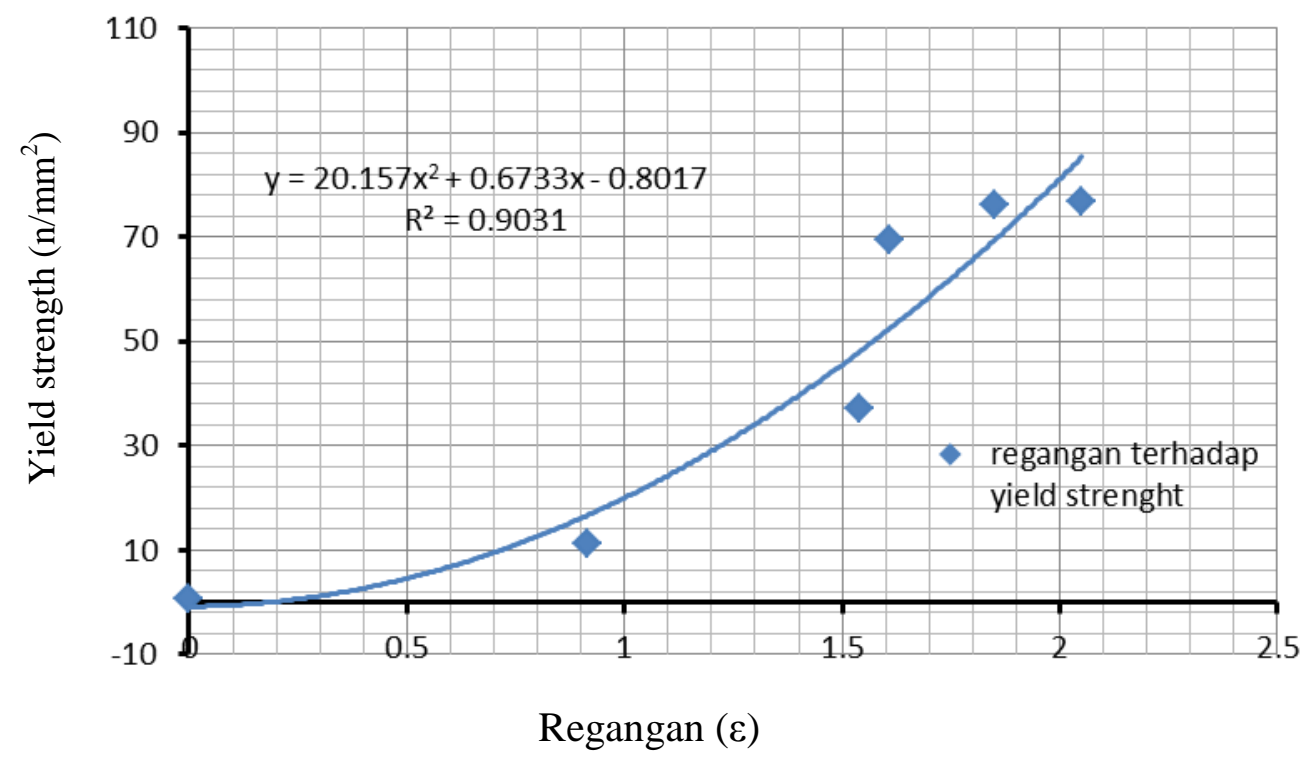

Gambar 6. Grafik hubungan antara regangan deformasi dengan yield strength 


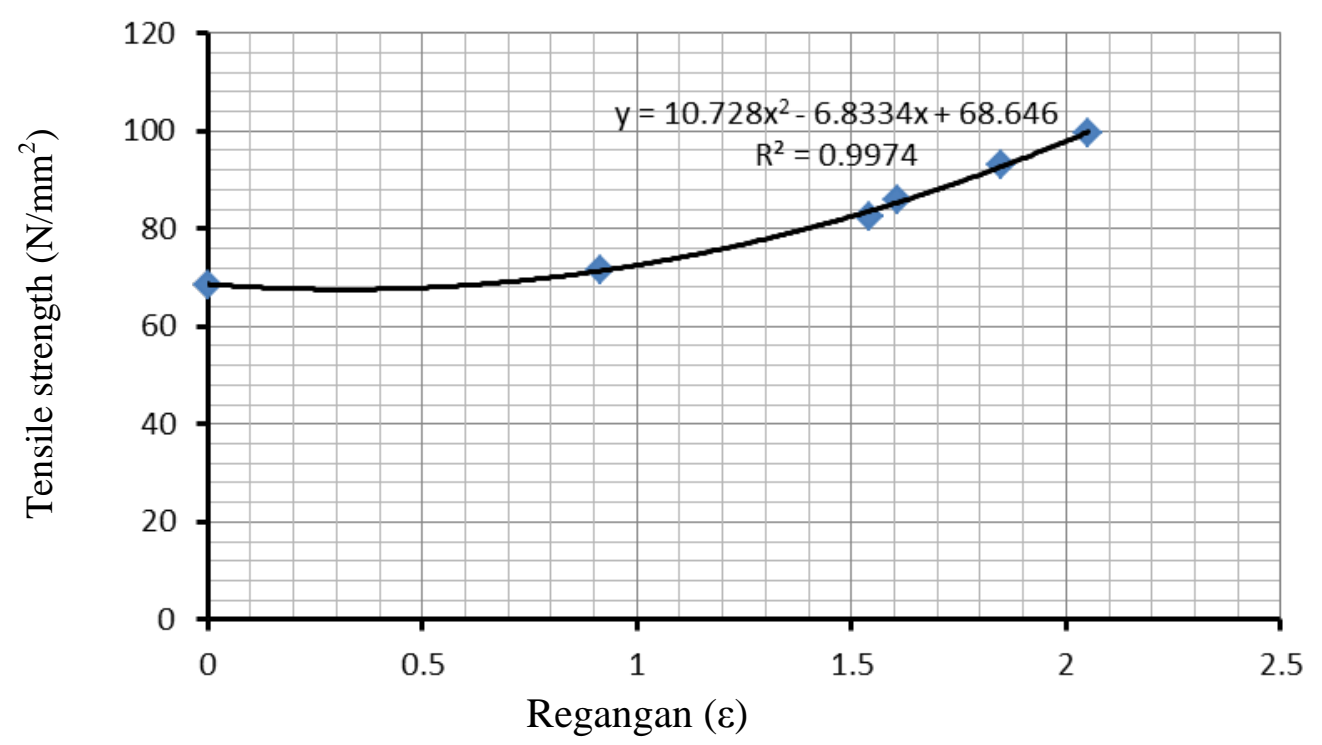

Gambar 7. Grafik hubungan antara regangan deformasi dengan tensile strength

Tabel 7. Regangan deformasi, yield strength dan tensile strength

\begin{tabular}{ccc}
\hline$\varepsilon$ & Yield strength $\left(\mathrm{N} / \mathrm{mm}^{2}\right)$ & Tensile strength $\left(\mathrm{N} / \mathrm{mm}^{2}\right)$ \\
\hline 0,5 & 5 & 70 \\
\hline 1 & 20 & 75 \\
\hline 1,5 & 45 & 80 \\
\hline 2 & 80 & 89 \\
\hline
\end{tabular}

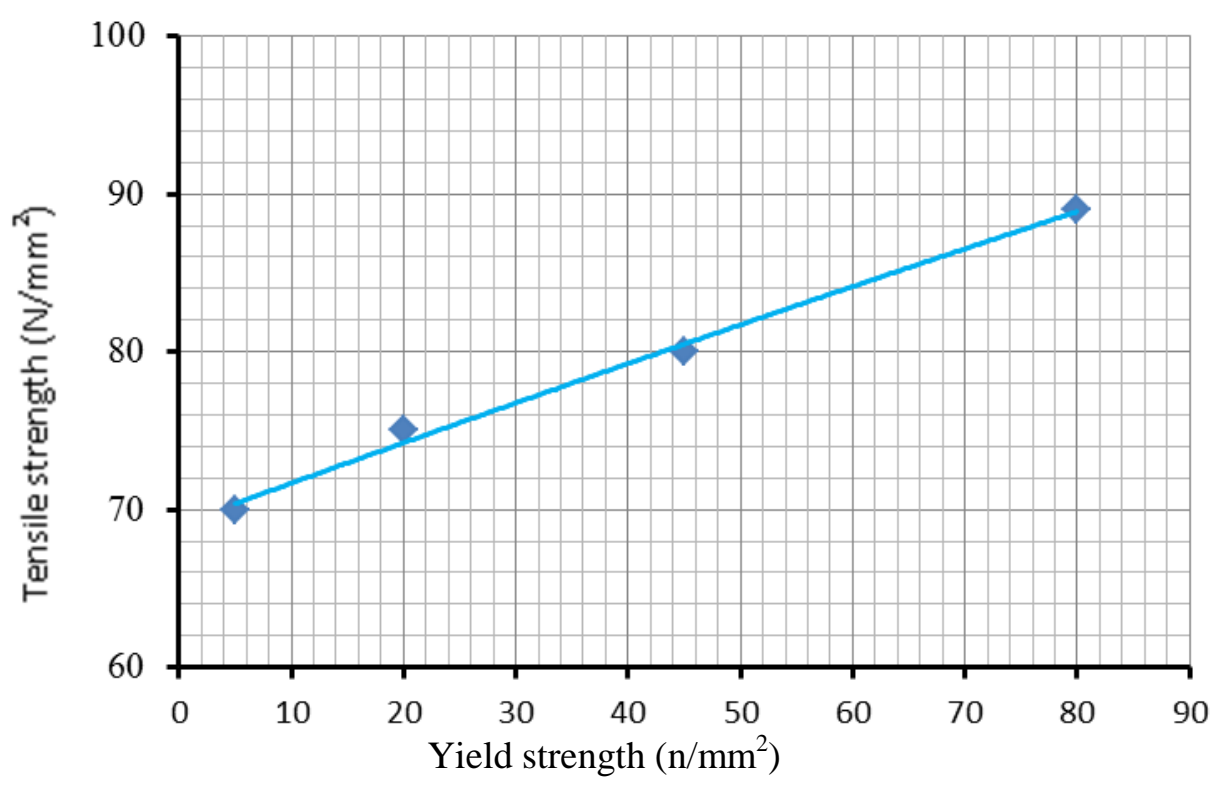

Gambar 8. Grafik hubungan antara yield strength dengan tensile strength

Kuningan yang digunakan pada percobaan ini adalah CuZn 70/30 yang memiliki komposisi kimia, sebelum di rol material tersebut dianil pada suhu $615^{\circ} \pm 5^{\circ} \mathrm{C}$ dan ditahan selama 90 menit. Dari proses anil tersebut diperoleh kekerasa rata-rata sebesar $77 \mathrm{HV}$ dengan ukuran diamerter butir rata-rata $30 \mu \mathrm{m}$ (pada Gambar 1 dapat dilihat struktur mikro kuningan setelah dianil).

Selanjutnya pelat kuningan dari ketelabalan awal $7 \mathrm{~mm}$ dirol dingin dengan berbagai reduksi total atau dengan berbagai ketebalan akhir yang berbeda. Pada Gambar 3 dapat dilihat hubungan antara rengangan akibat dirol dengan besar butir rata-rata dimana pada Gambar 3 terlihat bahwa 
semakin besar regangan mengakibatkan besar butir yang semakin halus. Sedangakan pada Gambar 4 dapat dilihat hubungan antara regangan dengan kekerasan dimana semakin besar regangan maka kekerasannya akan semakin meningkat kemudian pada Gambar 5 dan 6 dapat dilihat grafik hubungan antara regangan dengan yield strength dan tensile strength.

Dari percobaan W. Ozgowicz dapat juga dilihat bahwa semakin besar regangan makin kecil ukuran butir, namun percobaan W. Ozgowicz mengamati setelah proses anil pada masing-masing reduksi. Dari hubungan antara regangan dengan tensil strength dapat dibuat persamaan $\sigma_{\mathrm{uts}}=302,5 \times \varepsilon^{2,35}$.

\section{KESIMPULAN}

Pengerolan dari kuningan CuZn70/30 setelah mengalami proses anil pada suhu $610^{0} \pm 5^{\circ} \mathrm{C}$ mengakibatkan peningkatan sifat mekanik dan sifat plastis. Pengerolan dingin dari kuningan CuZn 70/30 mengakibatkan menaiknya kekerasan 211,67 HV. Pengerolan dingin dari kuningan CuZn 70/30 menghasilkan struktur mikro yang halus yang rata-rata kurang dari $10 \mu \mathrm{m}$. Pengerolan dari kuningan CuZn 70/30 menaikan tingkat keuletan dari kuningan tersebut. Hubungan antara tensile strength dan regangan deformasi untuk CuZn 70/30, secara empiris dapat ditulis $\sigma_{\text {uts }}=302,5 \times \varepsilon^{2,35}$. Hubungan antara tensile strength dan yield strength deformasi untuk CuZn 70/30 secara empiris dapat ditulis $\sigma_{\mathrm{uts}}=50+18,5 \sigma_{\mathrm{y}}^{0,05}$.

\section{DAFTAR PUSTAKA}

[1]. http://pwatlas.mt.umist.ac.uk/internetmicroscope/components/plug/wire-fixing screw/phase.html

[2]. http://www.alatuji.com/article/detail/3/what-is-hardness-test-uji-kekerasan-\#.T-hmhrU0PGA

[3]. http://www.infometrik.com/2009/09/mengenal-uji-tarik-dan-sifat-sifat-mekanik-logam/

[4]. Valiev Rz, islamgaliev RK, alexndrov IV. Bulk Nanostructured Materials From Severe Plastic Deformation. Progress in material science 45.2000

[5]. Dierter, G.E., Mechanical Metallurgy. SI metric edition, Mcgraw-hill, ISBN 0-07-100406b.1988.

[6]. ASTM, The Handbook of Standardiztion; the American Society for testing and material, ASTM Internasional.

[7]. Jeffries, Z., Kline, A. H., and Zimmer, E. B., “The Determination of the Average Grain Size in Metals, Transactions, American Institute of Mining and Metallurgical Engineers, Vol 54, 1917, pp. 594-607.

[8]. W. Ozgowicz, E. Kalinowska-Ozgowicz, B. Grzegorczyk, The microstructure and mechanical properties of the aloy CuZn30 after recrystallizion annealing, Journal of Achievements in Materials and Manufacturing Engineering 29/2 .PP.123-136. 2008 